Article

\title{
Effect of Ti on Microstructure and Properties of Tungsten Heavy Alloy Joint Brazed by CuAgTi Filler Metal
}

\author{
Yuzhen Lu $^{1}$, Xiaoming Qiu ${ }^{1}$, Ye Ruan ${ }^{1}$, Cui Luo ${ }^{1}$ and Fei Xing ${ }^{1,2, *}$ \\ 1 Key Laboratory of Automobile Materials of Ministry of Education, School of Materials Science and \\ Engineering, Jilin University, Changchun 130022, China; luyz16@mails.jlu.edu.cn (Y.L.); \\ qiuxm16@hotmail.com (X.Q.); ruanye@jlu.edu.cn (Y.R.); luocui16@mails.jlu.edu.cn (C.L.) \\ 2 Key of Laboratory of Automotive Simulation and Control, Jilin University, Changchun 130022, China \\ * Correspondence: xingfei16@outlook.com; Tel.: +86-0431-85094357
}

Received: 5 March 2019; Accepted: 28 March 2019; Published: 30 March 2019

\begin{abstract}
In this paper, scanning electron microscopy (SEM), energy dispersive spectroscopy (EDS) and X-ray diffractometer (XRD) were used to comprehensively analyze the microstructure and brazing performance of a CuAgTi filler metal with braze tungsten heavy alloys. The association of microstructure, wettability and shear strength of brazing joints was also investigated. With the addition of $\mathrm{Ti}$, the $\mathrm{Ti}_{3} \mathrm{Cu}_{4}$ phase appeared in the microstructure of filler metal. Ti is active element that promotes the reaction of filler with tungsten. Therefore, the Ti element is enriched around tungsten and forms a $\mathrm{Ti}_{2} \mathrm{Cu}$ layer at the interface, leaving a $\mathrm{Cu}$-rich/Ti-poor area on the side. Remaining $\mathrm{Ti}$ and $\mathrm{Cu}$ elements form the acicular $\mathrm{Ti}_{3} \mathrm{Cu}_{4}$ structure at the center of the brazing zone. The wettability of filler metal is improved, and the spreading area is increased from $120.3 \mathrm{~mm}^{2}$ to $320.9 \mathrm{~mm}^{2}$ with the addition of $10 \mathrm{wt} . \%$ Ti. The shear strength of joint reaches the highest level at a Ti content of $2.5 \mathrm{wt} . \%$, the highest shear strength is $245.6 \mathrm{MPa}$ at room temperature and $142.2 \mathrm{MPa}$ at $400{ }^{\circ} \mathrm{C}$.
\end{abstract}

Keywords: tungsten heavy alloy; brazed; active element; Ti

\section{Introduction}

Tungsten heavy alloys are composite materials while $\mathrm{W}$ is used as the hard phase and $(\mathrm{Ni}$, $\mathrm{Cu}),(\mathrm{Ni}, \mathrm{Fe})$ are used as the binder phases [1,2]. Tungsten heavy alloy is one of the most attractive metals for the nuclear industry, turbine and rocket power systems and machinery manufacturing applications due to their excellent properties such as high strength, good thermal conductivity, low thermal expansion coefficients and high corrosion resistance [3,4]. However, Tungsten heavy alloy is produced by a powder metallurgy process which is difficult to be machined, resulting in the urgently need for welding to form large or complex structures. The poor weldability of tungsten heavy alloy restricts the development and application in tungsten heavy alloy components.

Tungsten and its alloys tend to cause incomplete fusion during fusion welding because of their high melting point and thermal conductivity. The joining of tungsten alloys has been achieved by several procedures: brazing [5-7], diffusion bonding [8-10] and laser brazing [11]. Among them, high temperature brazing seems to be the most suitable method because of its limited influence on properties of base materials. In order to braze tungsten alloy, various components of filler metals have been investigated, such as Fe-based filler metals [12,13], Ni-based filler metals [14,15] and Cu-based filler metals $[16,17]$. However, when the brazing temperature is above the recrystallization temperature of $\mathrm{W}$ (1100-1370 $\left.{ }^{\circ} \mathrm{C}\right)$, performance changes of base metals such as grain growth, harden, and embrittlement could occur because of the high melting point of filler metals [18]. Cu-Ag alloys have been widely applied as brazing filler metals due to their superiority of strength, plasticity and weldability. Ti is active 
element which is investigated as reactive filler metals for brazing of ceramics [19-21] and cemented carbide [22,23] which are difficult to weld. In addition, Ti has a higher solubility in W. Researchers have tried to extend the application of Ti to braze of tungsten alloys. Chiachen Lin et al. studied $\mathrm{Pd}$ and Ti foils with different thicknesses, for brazing of tungsten and molybdenum in vacuum at temperatures between 1580 and $1740{ }^{\circ} \mathrm{C}$ for $10 \mathrm{~min}$, the result shows that brazed joint by Ti foils is full of voids/cracks. The reason for this is that the dissolution of $\mathrm{W}$ into the filler metal causes an increase in the solidus and liquidus temperatures of filler metal, so there is insufficient liquid to fill up the joint [24]. J. de Prado et al. studied Fe-Ti filler metal for W-W brazing joint which brazed in a high vacuum furnace at $1350{ }^{\circ} \mathrm{C}$ for $10 \mathrm{~min}$, the shear strength of the joints is $94 \pm 23 \mathrm{MPa}$, and failure during testing is always located at the tungsten-braze interface, because no further reactions or interactions were observed at the W-braze interface [25].

Considering the problem that the brazing temperature of the tungsten-based powder alloy using Fe-based or Ni-based brazing filler metal is higher than the recrystallization temperature of tungsten, this paper used a Cu-30Ag base filler metal and added a Ti element to promote its interaction with base metal. The research of Shang J has proved that the Cu-69.5Ag-3.5Ti filler metal had good wettability on the pure $\mathrm{W}$ plate, which has the same main component as the tungsten-based powder alloy [26]. The addition of Ti will produce intermetallic compounds in the joint, and excessive Ti will reduce the mechanical properties of the joint. Therefore, this paper further studied the influence of Ti on the microstructure and mechanical properties of the joints, and found the most suitable Ti content to provide a basis for optimizing the filler composition.

\section{Materials and Methods}

A tungsten heavy alloy plate used in the study is made by $97 \mathrm{wt} . \% \mathrm{~W}, 1.7 \mathrm{wt} . \% \mathrm{Ni}$ and $1.3 \mathrm{wt} . \% \mathrm{Fe}$. As can be seen from Figure 1, tungsten heavy alloy is composite material which consisted of tungsten particle and binder phase. The plates are treated with the surface preparation consisting of mechanical polishing with 1000 grit $\mathrm{SiC}$ abrasive followed by an ultrasonic cleaning in acetone, rinsed successively in ethanol and then dried with warm air. CuAgTi filler metals is prepared by mixing of $\mathrm{Cu}, \mathrm{Ag}$ and $\mathrm{Ti}$ metal powders according to the ratio of Table 1, then smelting in TL1400 high-vacuum furnace (TL1400, Nanjing Boyuntong Instrument Inc., Nanjing, China) at a maximum pressure of $7.6 \times 10^{-3} \mathrm{~Pa}$, at 1050 ${ }^{\circ} \mathrm{C}$ holding for $30 \mathrm{~min}$.

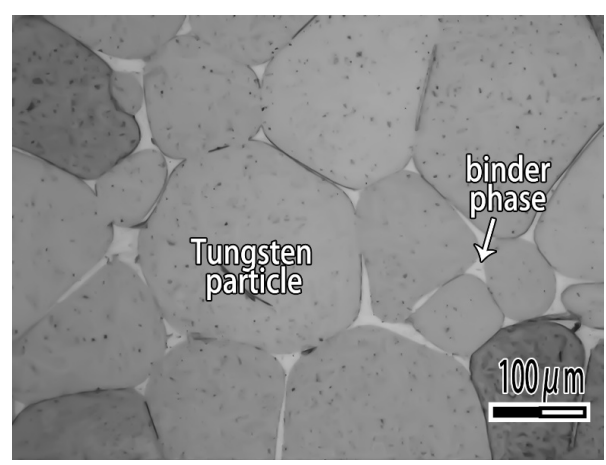

Figure 1. Microstructure of tungsten heavy alloy.

Table 1. Chemical compositions of filler metal (wt.\%).

\begin{tabular}{ccccccc}
\hline Element & $\mathbf{1}$ & $\mathbf{2}$ & $\mathbf{3}$ & $\mathbf{4}$ & $\mathbf{5}$ & $\mathbf{6}$ \\
\hline $\mathbf{C u}$ & 70 & 69 & 67.5 & 65 & 62.5 & 60 \\
$\mathbf{A g}$ & 30 & 30 & 30 & 30 & 30 & 30 \\
$\mathbf{T i}$ & - & 1 & 2.5 & 5 & 7.5 & 10 \\
\hline
\end{tabular}


The wetting experiments are carried out on the tungsten heavy alloy plates ( $20 \mathrm{~mm}$ (in Width) $\times$ $20 \mathrm{~mm}$ (in Length) $\times 2 \mathrm{~mm}$ (in Thickness)) with a similar ball filler of $0.30 \mathrm{~g}$ placed on it. The wetting experiment samples are produced in TL400 high-vacuum brazing furnace at $1100{ }^{\circ} \mathrm{C}$ holding for $10 \mathrm{~min}$ with a pressure of $5 \times 10^{-3} \mathrm{~Pa}$. Take the sample out and measure the spreading area after solidification and cooling to room temperature. The prepared wetting samples are shown in Figure 2. The shear strength experiments samples are processed the two matrix plates overlap with the dimension of $30 \mathrm{~mm}$ (in Length) $\times 15 \mathrm{~mm}$ (in Width) $\times 2 \mathrm{~mm}$ (in Thickness), as shown in Figure 3a. Dead load of $20 \mathrm{~g}$ is applied on top of the overlap joint assemblies to provide a slight bonding load. Then we placed them in a vacuum furnace and heated them at the same temperature and pressure as for wetting experiments. The shear strength tests are performed at ambient and high temperature on an electronic universal experimental machine (INSTRON-5869, INSTRON Inc., Norwood, MA, USA) at a constant speed of $1 \mathrm{~mm} / \mathrm{min}$ with the aid of a fixture. The schematic diagram of shear strength tests is shown in Figure $3 \mathrm{~b}$. The microstructures, element distribution and fracture morphology analysis of the brazed samples were performed using Micro X-ray diffractometer (XRD, D8 Discover with GADDS, BRUKER, Karlsruhe, Germany) and scanning electron microscopy (SEM, S-3400N, HITACHI, Kyoto, Japan) equipped with an energy dispersive spectroscopy (EDS, Genesis XM, EDAX Inc., Mahwah, NJ, USA).

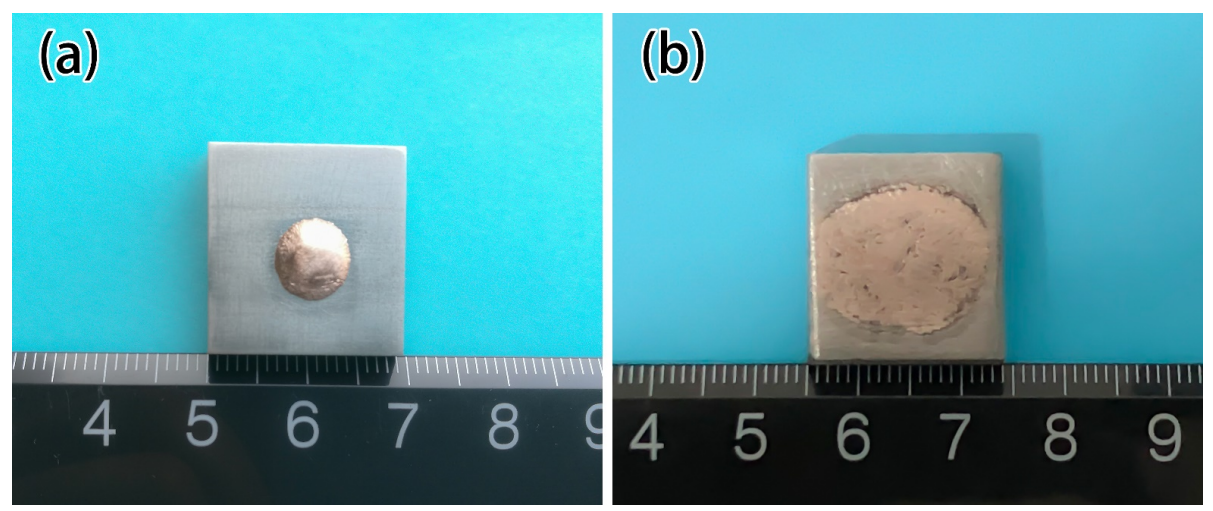

Figure 2. Wettability sample of CuAgTi filler metal. (a) Ti 1 wt.\%; (b) Ti 7.5 wt.\%.

(a)

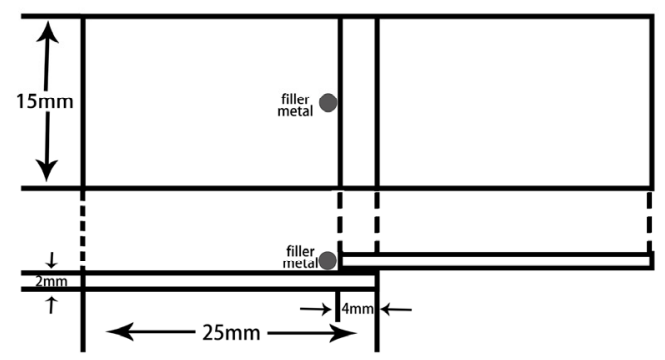

(b)

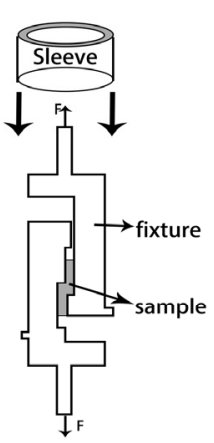

Figure 3. Schematic diagram. (a) Brazing joints; (b) Shear strength tests.

\section{Results and Discussions}

\subsection{Filler Metal}

Figure 4 is the XRD pattern of CuAgTi filler metal, it shows that the filler metals consist of $\alpha$-Cu, $\beta-\mathrm{Ag}$ and a small amount of intermetallic phases $\mathrm{Ti}_{3} \mathrm{Cu}_{4}$. Figure 5 exhibits the microstructure of $\mathrm{CuAgTi}$ filler metals with different Ti content. It can be seen that the microstructure is similar to $\mathrm{Cu}-\mathrm{Ag}$ binary alloy (Figure 5a), and consisted of black $\alpha-\mathrm{Cu}$ and white $\beta$-Ag while the Ti content is less than 2.5 wt.\%. When Ti content exceeds 7.5 wt.\% (Figure 5c,e), a rectangular structure appeared, which was augment with the increasing of the Ti content. XRD and EDS (Table 2) reveal that the Ti element 
aggregates in the form of Ti solidus solution at the junction of copper and silver, as shown by point A in Figure 5b. With the increasing of the Ti content, the rectangular structure that appeared is the $\mathrm{Ti}_{3} \mathrm{Cu}_{4}$ intermediate phase, which is marked B in Figure $5 \mathrm{~d}$, and the Ti element mainly exists in this form. When the Ti content is $10 \mathrm{wt}$.\%, the filler metal consisted of white $\beta$-Ag matrix (point F), oval $\alpha-\mathrm{Cu}$ (point E) and rectangular $\mathrm{Ti}_{3} \mathrm{Cu}_{4}$ phase (point D) in Figure $5 \mathrm{f}$.

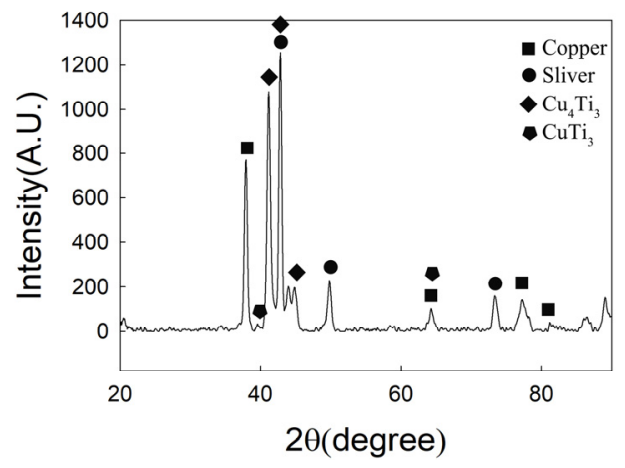

Figure 4. XRD Pattern of CuAgTi filler metals.
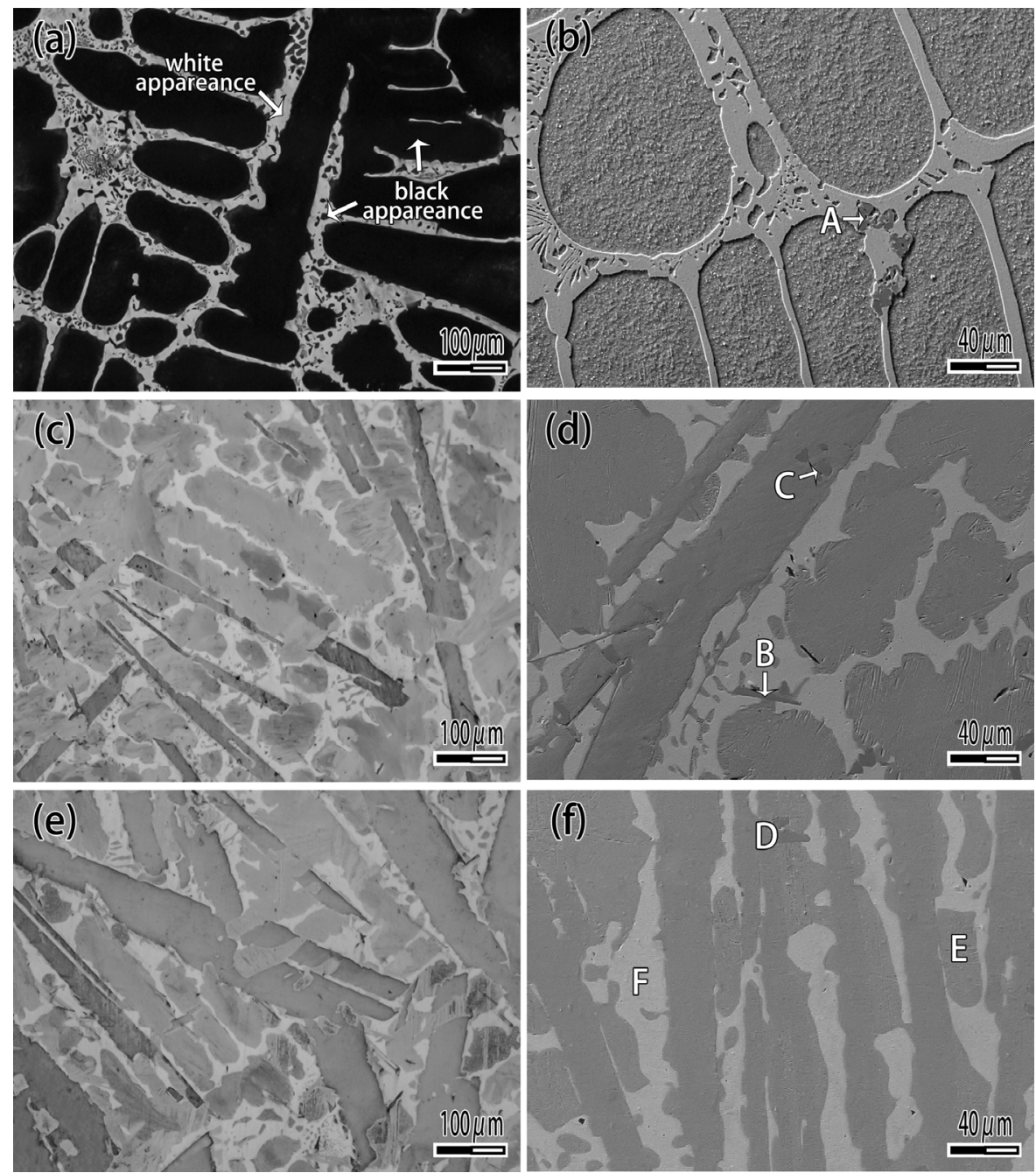

Figure 5. Microstructure of CuAgTi filler metal. (a) 1 wt.\% Ti; (b) Magnified of 1 wt.\% Ti; (c) 7.5 wt.\% $\mathrm{Ti}$; (d) Magnified of 7.5 wt.\% Ti; (e) 10 wt.\% Ti; (f) Magnified of 10 wt.\% Ti. 
Table 2. EDS analysis of CuAgTi filler metal (at.\%).

\begin{tabular}{ccccc}
\hline Point & Cu (at.\%) & Ag (at.\%) & Ti (at.\%) & Phase \\
\hline A & 12.21 & 5.74 & 82.05 & $\alpha-\mathrm{Ti}$ \\
B & 54.47 & 3.69 & 41.84 & $\mathrm{Ti}_{3} \mathrm{Cu}_{4}$ \\
C & 53.12 & 1.96 & 44.92 & $\mathrm{Ti}_{3} \mathrm{Cu}_{4}$ \\
D & 59.04 & 1.03 & 39.93 & $\mathrm{Ti}_{3} \mathrm{Cu}_{4}$ \\
E & 92.85 & 5.73 & 1.42 & $\alpha-\mathrm{Cu}$ \\
F & 15.10 & 84.49 & 4.41 & $\beta-\mathrm{Ag}$ \\
\hline
\end{tabular}

Figure 6 exhibits the effect of $\mathrm{Ti}$ on the spreading area of filler metal. In test range, the spreading area of the filler is $120.31 \mathrm{~mm}^{2}$ with $1 \mathrm{wt} . \%$ Ti added, as shown in Figure 2a. With $5 \mathrm{wt} . \%$ Ti added, the spreading area rapidly increased to $186.3 \mathrm{~mm}^{2}$, and reached $283.8 \mathrm{~mm}^{2}$ with $7.5 \mathrm{wt} . \% \mathrm{Ti}$ added, as shown in Figure $2 \mathrm{~b}$. When Ti content is $10 \mathrm{wt} . \%$, the spreading area is $40 \mathrm{~mm}^{2}$ which is more than 7.5 wt.\%. As shown in Figure 2, when the Ti content is $7.5 \mathrm{wt} . \%$, the spreading area is much larger than the Ti content of $1 \mathrm{wt} . \%$, the wettability is significantly improved. It can be seen that while the Ti content is $7.5 \mathrm{wt} . \%$, the microstructure of filler metal changes, forming a rectangular $\mathrm{Ti}_{3} \mathrm{Cu}_{4}$ phase, the spreading area obviously also increased to $283.8 \mathrm{~mm}^{2}$.

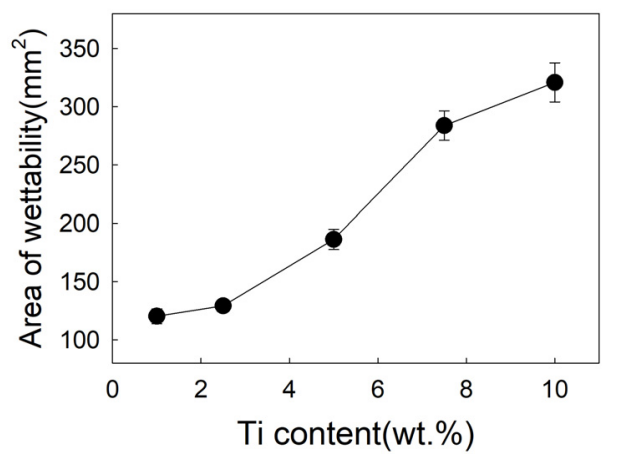

Figure 6. Influence of Ti content on spreading area.

\subsection{Microstructure of brazing joint}

Figure 7 exhibits the microstructure of brazing joint with different Ti content. It can be seen that when the Ti content is 1 wt.\% (Figure 7a), the microstructure of brazing zone consisted of $\alpha$-Ag and $\beta-\mathrm{Cu}$, which is not significantly different from joint brazed by $\mathrm{CuAg}$ binary alloy. With the Ti content increasing (Figure 7b,c), the rectangular and acicular structure appeared, and a black reaction layer was produced at the interface. With the Ti content increasing (Figure 7c), the number of rectangular structures was raised. When the Ti content is $10 \mathrm{wt}$ \% (Figure 7d), the filler metal reacted strongly with the binder phase of tungsten heavy alloy, and a phenomenon similar to intergranular infiltration occurred, so that the tungsten particles entered the filler metal as shown in Figure 7d. Figure 8 is the detail of microstructure of joint with $10 \%$ Ti content. As Figure 8 exhibits with EDS analysis (The results are shown in Table 3), the rectangular structure is the $\mathrm{Ti}_{2} \mathrm{Cu}$ phase marked $\mathrm{A}$, and the acicular phase is the $\mathrm{Ti}_{3} \mathrm{Cu}_{4}$ phase marked $\mathrm{B}$, as shown in Figure 8a. The Ag element mainly exists in the gap between acicular $\mathrm{Ti}_{3} \mathrm{Cu}_{4}$ phase (point $\mathrm{C}$ ). The reaction layer at the interface is $\mathrm{Ti}_{2} \mathrm{Cu}$ phase too. Several tungsten particles are intercalated in the reaction layer such as point E, and occasionally there are solid solution of $\alpha$-Ti around the tungsten particles (Figure $8 b$ ). 

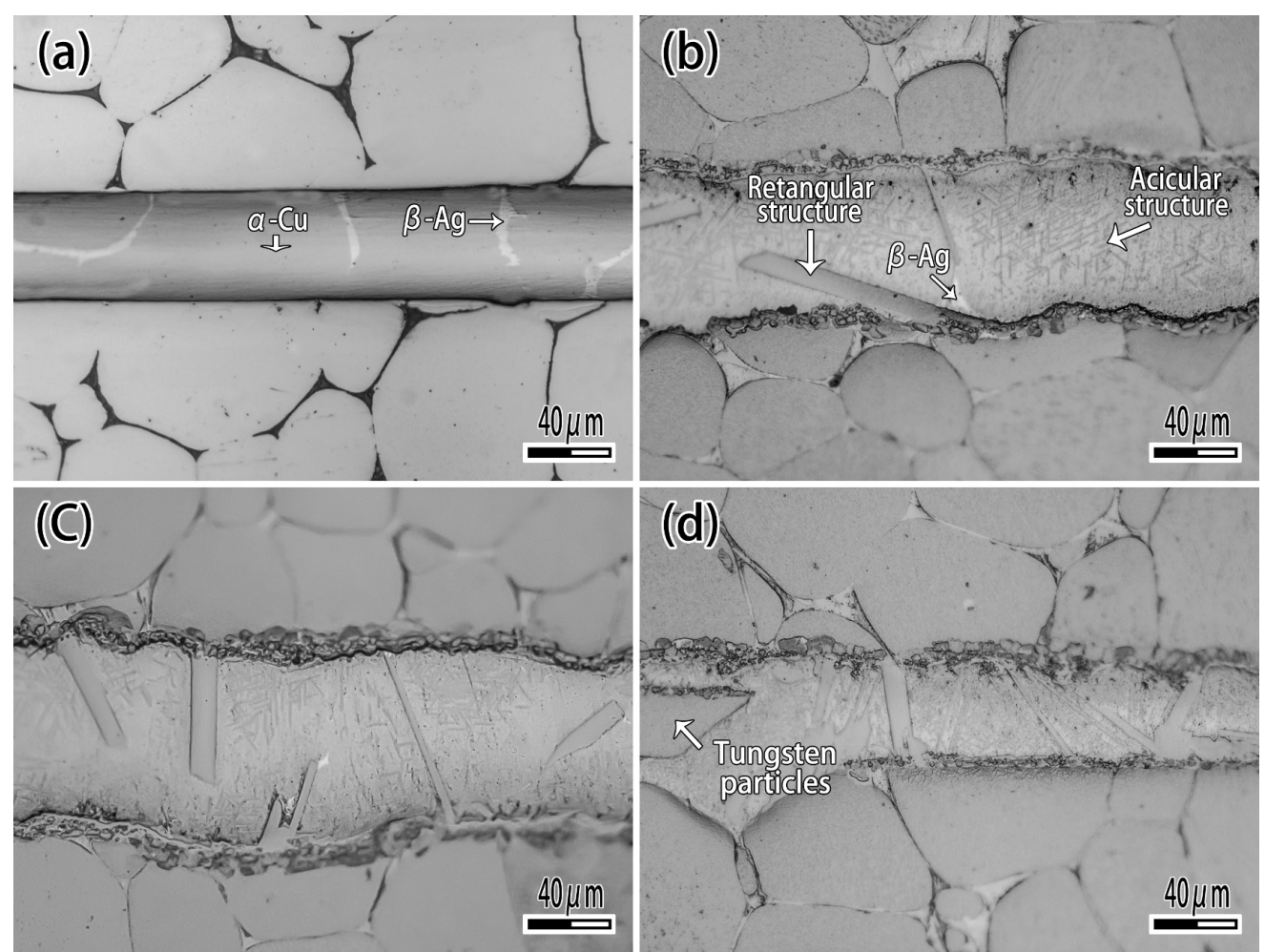

Figure 7. The effect of Ti on microstructure of joint. (a) Ti 1 wt.\%; (b) Ti 2.5wt.\%; (c) Ti 5 wt.\%; (d) Ti 10 wt. $\%$.
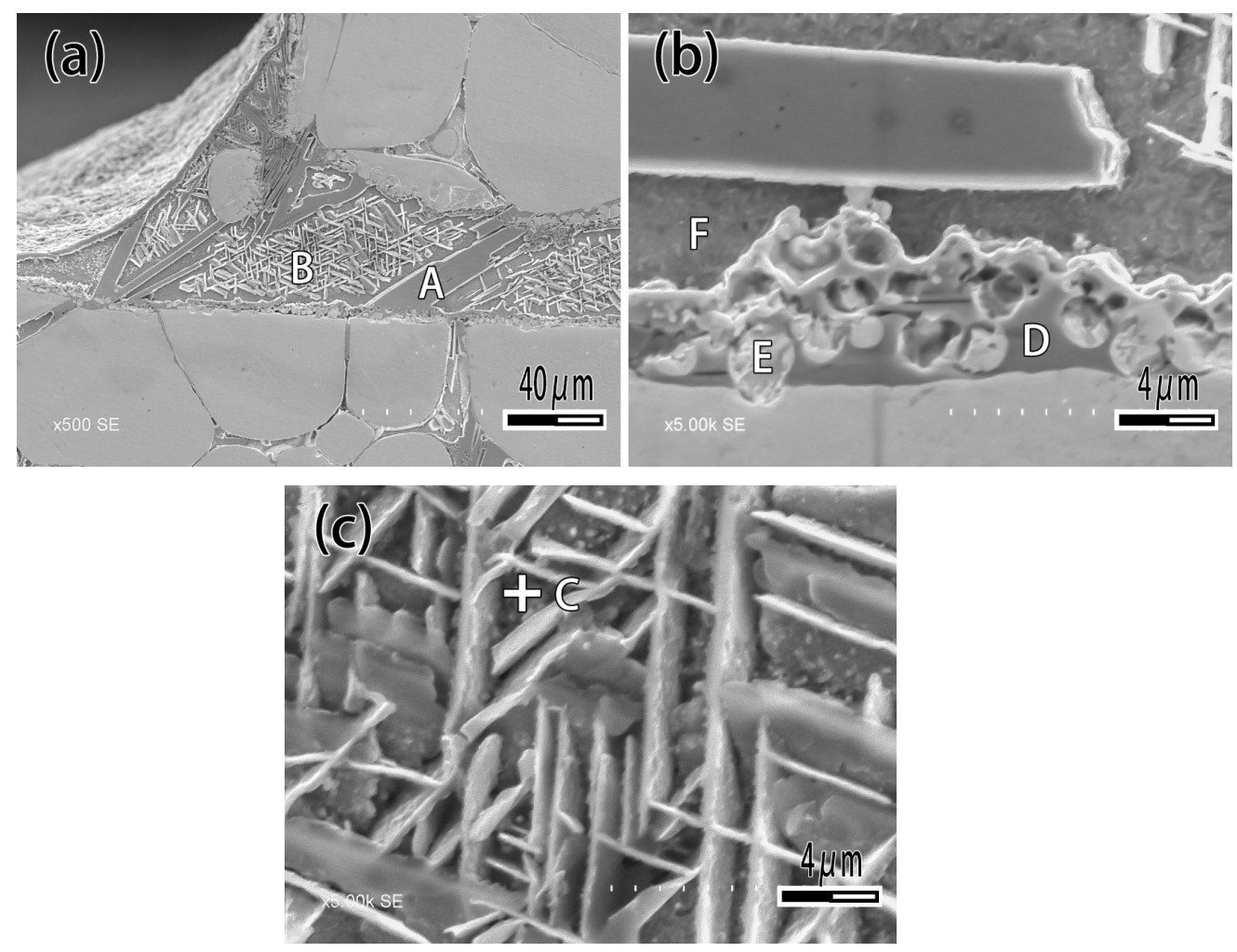

Figure 8. Microstructure of joint brazed by CuAg-10Ti filler metal. (a) Joint; (b) Interface; (c) Brazing central zone. 
Table 3. EDS analysis of brazed joint.

\begin{tabular}{cccccc}
\hline Point & Cu (at.\%) & Ag (at.\%) & Ti (at.\%) & W (at.\%) & Phase \\
\hline A & 53.47 & 3.99 & 40.67 & 1.87 & $\mathrm{Ti}_{3} \mathrm{Cu}_{4}$ \\
B & 62.44 & 2.04 & 30.94 & 4.57 & $\mathrm{Ti}_{2} \mathrm{Cu}$ \\
C & 8.73 & 90.17 & 1.10 & - & $\beta-\mathrm{Ag}$ \\
D & 27.35 & 1.34 & 63.91 & 7.39 & $\mathrm{Ti}_{2} \mathrm{Cu} \& \alpha-\mathrm{Ti}$ \\
E & 0.67 & 0.22 & 3.34 & 95.77 & $\mathrm{~W}$ granule \\
F & 71.56 & 6.99 & 3.24 & 2.47 & $\alpha-\mathrm{Cu}$ \\
\hline
\end{tabular}

The element content of line scanning analysis of brazing joint is shown in Figure 9. The joint is divided into parts I, II, III and IV. Part I is base metal. Part II is a Ti-rich layer, and the W element content of line scanning forms an interlude step in this layer, W element dissolves more in this layer. Part III is Cu-rich layer, in which small amount of another element dissolved. Part IV is the center of brazing zone. This process of wetting and jointing can be regarded as an interface adsorption model of an active element, as shown as Figure 10. According to an Ag-Cu-Ti ternary alloy phase diagram (Figure 11), the filler metal should be separated into two liquid phases which are incompatible after melting into liquid, and one is rich in $\mathrm{Cu}$ and $\mathrm{Ti}$, the other one is rich in $\mathrm{Ag}$. Ti is active element which is able to react with $\mathrm{W}$, so Ti is preferentially adsorbed on the surface of tungsten heavy alloy, while a $\mathrm{Ti}_{2} \mathrm{Cu}$ layer is formed at the interface, with a small amount of $\mathrm{W}$ diffusion inside. Concurrently, a Ti-poor area containing plenty of copper formed near the $\mathrm{Ti}_{2} \mathrm{Cu}$ layer. At the center of the brazing zone, $\mathrm{Cu}$ and $\mathrm{Ti}$ element remained form the acicular $\mathrm{Ti}_{3} \mathrm{Cu}_{4}$ phase, and the $\mathrm{Ti}_{3} \mathrm{Cu}$, phase separates out with a Ag-rich phase.

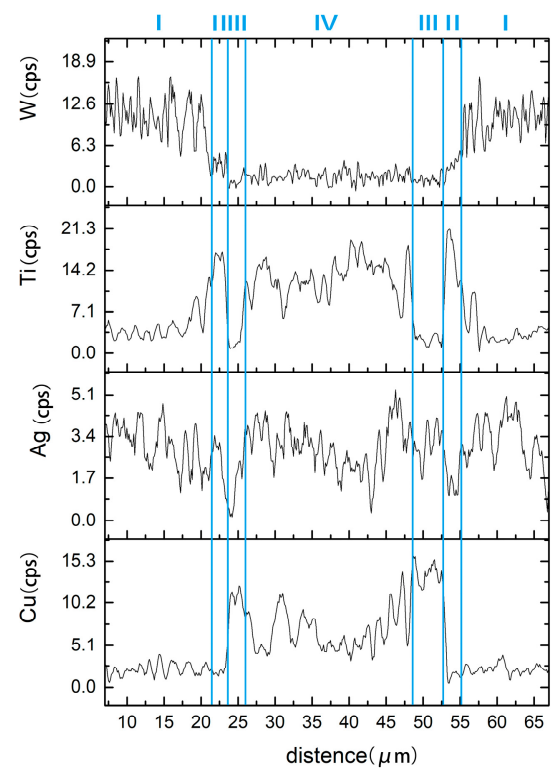

Figure 9. Line scan across the brazed joint. 
Step1:Inert balance

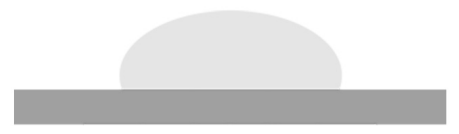

Step2:Ti element adsorption

\&reactant with tungsten

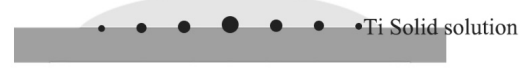

Step3:Final wetting balance

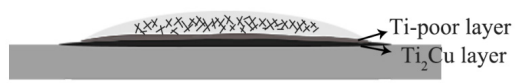

Figure 10. Wetting model.

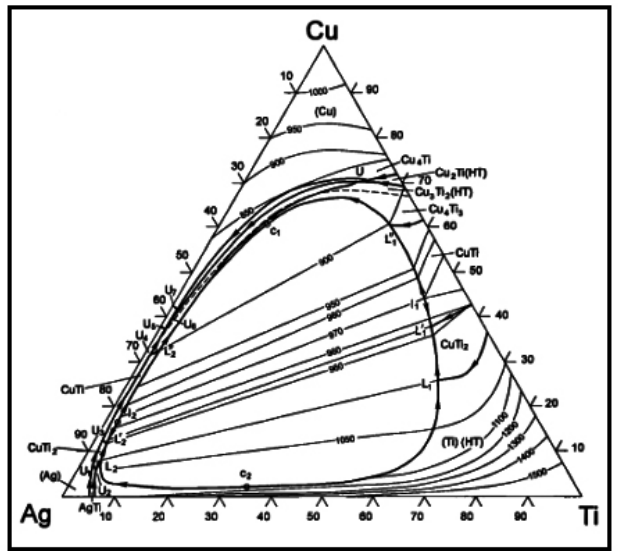

Figure 11. Ag-Cu-Ti ternary alloy phase diagram.

\subsection{Mechanical Properties}

Figures 12 and 13 show the shear strength and fracture morphology of the joint with different Ti content brazed at $1050{ }^{\circ} \mathrm{C}$ for $10 \mathrm{~min}$. In the test range, the shear strength of the joint is $162.8 \mathrm{MPa}$ with no Ti. As the increasing of Ti content occurs, the shear strength of joint increases, which reached a maximum of $245.6 \mathrm{MPa}$ while the Ti content is $2.5 \mathrm{wt} . \%$. When continuing to add the Ti element, the shear strength of brazed joint decreased slightly, decreasing to $240.9 \mathrm{MPa}$ at 5 wt. $\%$ Ti content, and decreasing to $220 \mathrm{MPa}$ at $10 \mathrm{wt}$.\% Ti content. As shown in Figure 13, the joint fractured mixed the characteristics of fragility and ductile. When Ti content is $1 \mathrm{wt}$ \% (Figure 13a), it can be seen that the joint is crystalline fracture, which means there is joint insecurity. The diffusion of $\mathrm{Ti}$ and the formation of the reaction layer improve the shear strength of joint and reaches the highest level at $2.5 \mathrm{wt} . \%$. Then an excessive Ti element causes the dissolution of the base metal into the filler metal, resulting in the inclusion of tungsten particles in the reaction layer and reducing shear strength of the joint. 


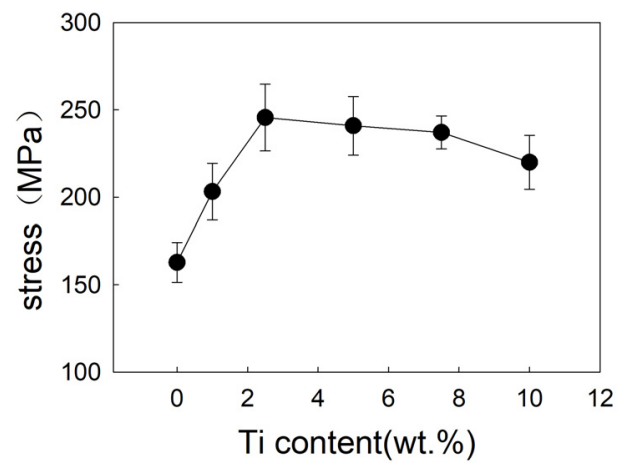

Figure 12. Influence of Ti content on shear strength of brazed joint.
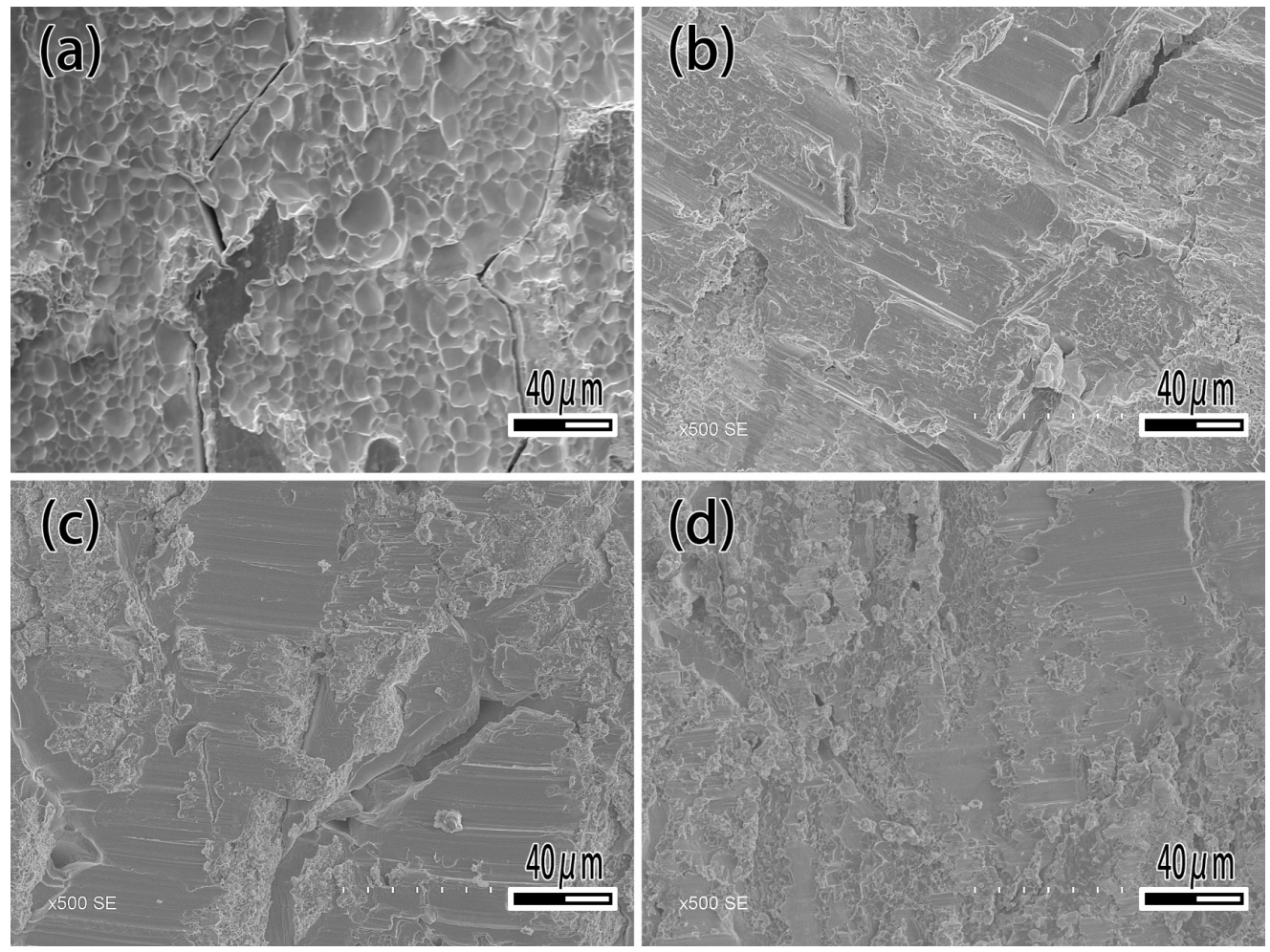

Figure 13. Fracture morphology of brazed joint. (a) Ti 1 wt.\%; (b) Ti 2.5 wt.\%; (c) Ti 7.5 wt.\%; (d) Ti 10 wt.\%.

As a die-casting mold, tungsten heavy alloy needs to withstand the repeated scouring of high temperature liquid, and high temperature properties are necessary for tungsten heavy alloy. Therefore, it is important to study the influence of temperature on the shear strength of a brazed joint. Figure 14 is the result of a high temperature performance test. Figure 14a shows the influence of temperature on the shear strength of a joint with different Ti contents, and Figure $14 \mathrm{~b}$ is a comparison of joints brazed by $\mathrm{CuAg}$ filler metal without Ti. The shear strength of joint brazed by $\mathrm{CuAg}$ filler metal at room temperature is $162.2 \mathrm{MPa}$, however it reduces to $63.6 \mathrm{MPa}$ at $400{ }^{\circ} \mathrm{C}$, decreased by $60.8 \%$. It can be seen that the Ti element can promote the shear strength of joint at room temperature and high temperature. After adding Ti element, the shear strength of joint at $400{ }^{\circ} \mathrm{C}$ has a range from 124.8 to 142.8 MPa. However, there is little difference in high temperature performance of the brazed joint with a different Ti content. 


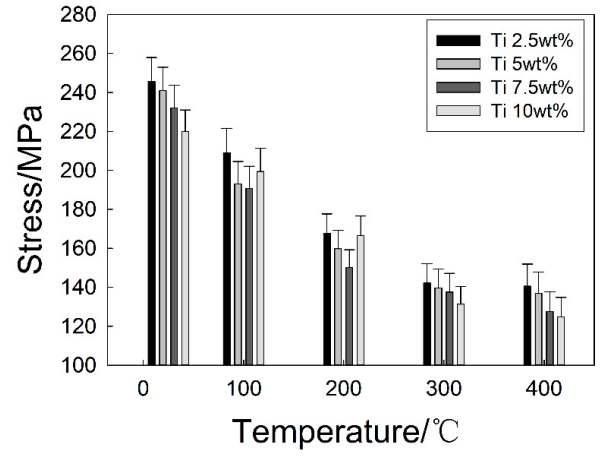

(a)

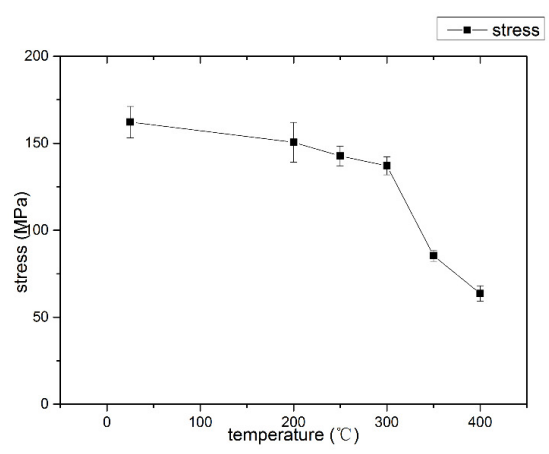

(b)

Figure 14. Influence of testing temperature on Shear Strength of brazed Joint. (a) CuAgTi filler metal; (b) without Ti.

\section{Conclusions}

In order to solve the two problems of controlling brazing temperature and intermetallic compound joint strength reduction caused by intermetallic compounds in the brazing of tungsten-based powder alloy, we chose $\mathrm{Cu}-30 \mathrm{Ag}$ as a base filler metal and added the Ti element to promote its interaction with base metal, then studied the influence of Ti on solder microstructure, joint structure and mechanical properties, concluding as follows.

The Ti element influences the microstructure of the filler metal. When the Ti content is less than $2.5 \mathrm{wt} . \%$, the microstructure of the $\mathrm{CuAgTi}$ filler metal consists of $\alpha-\mathrm{Cu}, \beta-\mathrm{Ag}$ and Ti solidus solution which were concentrated on the boundary between $\alpha-\mathrm{Cu}$ and $\beta$-Ag. With the addition of the Ti element, the rectangular $\mathrm{Ti}_{3} \mathrm{Cu}_{4}$ phase appeared in the filler metal. Ti element can promote the interface reaction between filler metal and base metal. During the brazing process, Ti elements are concentrated at the interface near base metal, forming a Ti-rich $\mathrm{Ti}_{2} \mathrm{Cu}$ layer. Then a $\mathrm{Cu}$-rich/Ti-poor layer formed near the $\mathrm{Ti}_{2} \mathrm{Cu}$ layer. Finally, the acicular $\mathrm{Ti}_{3} \mathrm{Cu}_{4}$ phase separated out together with the silver-rich phase.

Due to the promoting of the Ti element on the interfacial reaction, Ti has a great effect on improving the wettability of $\mathrm{CuAgTi}$ filler metal; with the increase of the Ti element, the spreading area increases from $120.31 \mathrm{~mm}^{2}$ to $283.87 \mathrm{~mm}^{2}$, while the area is increased by $135.9 \%$. Excessive Ti element promotes the dissolution of the base metal and reduces the strength of the joint. When the Ti content is $2.5 \mathrm{wt} . \%$, the shear strength of brazed joint at room temperature reaches the highest level, 245.6MPa. Meanwhile, the shear strength at $400{ }^{\circ} \mathrm{C}$ is $142.2 \mathrm{MPa}$, which is $100 \%$ higher than that without Ti. A significant difference in high temperature performance of the brazed joint with different Ti content has not been observed.

According to the test results, the wettability, mechanical properties and high temperature strength of the brazing filler metal are the best levels at Ti $2.5 \mathrm{wt} . \%$, while $\mathrm{Cu}-30 \mathrm{Ag}-2.5 \mathrm{Ti}$ is the most suitable component. Based on this, we hope to further study the effects of other active elements such as $\mathrm{Zr}$ or $\mathrm{Nb}$ in the next work and study their interaction with $\mathrm{Ti}$, optimize the composition of the brazing alloy, and obtain a brazed joint with better mechanical properties.

Author Contributions: Investigation and Writing-original draft, Y.L.; Conceptualization and Funding acquisition, X.Q.; Resources, Y.R.; Validation, C.L.; Writing-review \& editing, F.X.

Funding: This work was supported by Jilin Province Science and Technology Development Plan [project 20170204026GX].

Conflicts of Interest: The authors declare no conflict of interest. 


\section{References}

1. Fan, J.; Han, Y.; Li, P.; Sun, Z.; Zhou, Q. Micro/nano composited tungsten material and its high thermal loading behavior. J. Nuclear Mater. 2014, 455, 717-723. [CrossRef]

2. Liu, W.S.; Zhang, J.J.; Ma, Y.Z.; Zhao, Y.X.; Xu, G.; Huang, B.Y. Effect of Microwave Sintering Parameters on Microstructure and Mechanical Properties of Powder Extruded Rods of Tungsten-Based Alloy. Rare Met. Mater. Eng. 2012, 41, 1284-1288.

3. Skumavc, A.; Tušek, J.; Nagode, A.; Kosec, L. Tungsten heavy alloy as a filler metal for repair welding of dies for high pressure die casting. Int. J. Mater. Res. 2013, 104, 1143-1150. [CrossRef]

4. Rieth, M.; Dudarev, S.L.; de Gonzalez Vicente, S.M.; Aktaa, J.; Ahlgren, T.; Antusch, S.; Armstrong, D.E.J.; Balden, M.; Baluc, N.; Barthe, M.F.; et al. Recent progress in research on tungsten materials for nuclear fusion applications in Europe. J. Nuclear Mater. 2013, 432, 482-500. [CrossRef]

5. Zhang, Y.; Galloway, A.; Wood, J.; Robbie, M.B.O.; Easton, D.; Zhu, W. Interfacial metallurgy study of brazed joints between tungsten and fusion related materials for divertor design. J. Nuclear Mater. 2014, 454, $207-216$. [CrossRef]

6. Easton, D.; Zhang, Y.; Wood, J.; Galloway, A.; Robbie, M.O.; Hardie, C. Brazing development and interfacial metallurgy study of tungsten and copper joints with eutectic gold copper brazing alloy. Fusion Eng. Des. 2015, 98-99, 1956-1959. [CrossRef]

7. Hamilton, N.R.; Robbie, M.O.; Wood, J.; Galloway, A.; Katramados, I.; Milnes, J. The challenges in predicting the fatigue life of dissimilar brazed joints and initial finite element results for a tungsten to EUROFER97 steel brazed joint. Fusion Eng. Des. 2011, 86, 1642-1645. [CrossRef]

8. Cai, Q.; Liu, W.; Ma, Y.; Liu, H. Microstructure, residual stresses and mechanical properties of diffusion bonded tungsten-steel joint using a V/Cu composite barrier interlayer. Int. J. Refract. Met. Hard Mater. 2015, 48, 312-317. [CrossRef]

9. Wang, S.; Ling, Y.; Wang, J.; Xu, G. Microstructure and mechanical properties of W/Cu vacuum diffusion bonding joints using amorphous Fe-W alloy as interlayer. Vacuum 2015, 114, 58-65. [CrossRef]

10. Basuki, W.W.; Aktaa, J. Process optimization for diffusion bonding of tungsten with EUROFER97 using a vanadium interlayer. J. Nuclear Mater. 2015, 459, 217-224. [CrossRef]

11. Munez, C.J.; Garrido, M.A.; Rams, J.; Ureña, A. Experimental study of W-Eurofer laser brazing for divertor application. J. Nuclear Mater. 2012, 418, 239-248. [CrossRef]

12. Wang, J.; Lian, Y.; Feng, F.; Chen, Z.; Tan, Y.; Yang, S.; Liu, X.; Qiang, J.; Liu, T.; Wei, M. Microstructure of the tungsten and reduced activation ferritic-martensitic steel joint brazed with an Fe-based amorphous alloy. Fusion Eng. Des. 2019, 138, 164-169. [CrossRef]

13. De Prado, J.; Sánchez, M.; Wirtz, M.; Pintsuk, G.; Du, J.; Linke, J.; Ureña, A. Impact of thermal fatigue on W-W brazed joints for divertor components. J. Mater. Process. Technol. 2018, 252, 211-216. [CrossRef]

14. Sánchez, M.; Garrido, M.A.; Múnez, C.J.; Rams, J.; Ureña, A. Analysis of the brazeability of W-W joints using a high temperature Ni-based alloy. Mater. Des. 2014, 54, 900-905. [CrossRef]

15. Xia, C.; Sun, W.; Zhou, Y.; Zhao, M. Effect of Ni-Ti filler on brazed W-Cu/18-8 joints. J. Mater. Process. Technol. 2018, 259, 15-22. [CrossRef]

16. Prado, J.D.; Sánchez, M.; Ureña, A. Evaluation of mechanically alloyed Cu-based powders as filler alloy for brazing tungsten to a reduced activation ferritic-martensitic steel. J. Nuclear Mater. 2017, 490, 188-196. [CrossRef]

17. Liu, W.; Wang, Z.; Ma, Y.; Cai, Q. Investigation of tungsten/steel brazing using Ta and Cu interlayer. Fusion Eng. Des. 2016, 113, 102-118. [CrossRef]

18. L OLSON, D.; Mishra, B.; Wenman, D.W. Welding, brazing and joining of refractory metals and alloys. Miner. Process. Extr. Metall. Rev. 2001, 22,1-23. [CrossRef]

19. Dai, X.; Cao, J.; Chen, Z.; Song, X.; Feng, J. Brazing SiC ceramic using novel B4C reinforced Ag-Cu-Ti composite filler. Ceram. Int. 2016, 42, 6319-6328. [CrossRef]

20. Chen, Z.; Bian, H.; Niu, C.; Song, X.; Duan, X.; Cao, J.; Feng, J. Titanium-deposition assisted brazing of SiC ceramics using inactive AgCu filler. Mater. Charact. 2018, 142, 219-222. [CrossRef]

21. Yang, Z.W.; Zhang, L.X.; Xue, Q.; He, P.; Feng, J.C. Interfacial microstructure and mechanical property of $\mathrm{SiO}_{2}-\mathrm{BN}$ ceramics and Invar joint brazed with Ag-Cu-Ti active filler metal. Mater. Sci. Eng. A 2012, 534, 309-313. [CrossRef] 
22. Hasanabadi, M.; Shamsipur, A.; Sani, H.N.; Omidvar, H.; Sakhaei, S. Interfacial microstructure and mechanical properties of tungsten carbide brazed joints using Ag-Cu-Zn $+\mathrm{Ni} / \mathrm{Mn}$ filler alloy. Trans. Nonferrous Met. Soc. China 2017, 27, 2638-2646. [CrossRef]

23. Sechi, Y.; Tsumura, T.; Nakata, K. Dissimilar laser brazing of boron nitride and tungsten carbide. Mater. Des. 2010, 31, 2071-2077. [CrossRef]

24. Lin, C.C.; Shu, C.H.; Chen, C.; Shiue, R.K.; Shy, H.J. Brazing porous tungsten and molybdenum using palladium and titanium foils. Int. J. Refract. Met. Hard Mater. 2012, 31, 284-287. [CrossRef]

25. De Prado, J.; Sánchez, M.; Utrilla, M.V.; López, M.D.; Ureña, A. Study of a novel brazing process for W-W joints in fusion applications. Mater. Des. 2016, 112, 117-123. [CrossRef]

26. Shang, J.; Yan, J.; Li, N. Brazing W and Fe-Ni-Co alloy using Ag-28Cu and Ag-27Cu-3.5Ti fillers. J. Alloy. Compd. 2014, 611, 91-95. [CrossRef]

2019 by the authors. Licensee MDPI, Basel, Switzerland. This article is an open access article distributed under the terms and conditions of the Creative Commons Attribution (CC BY) license (http://creativecommons.org/licenses/by/4.0/). 